\title{
Risk assessment of traffic-related air pollution in a world heritage city
}

\author{
N. Sheng $\cdot$ U. W. Tang
}

Received: 22 August 2011/Revised: 20 October 2011/ Accepted: 22 January 2012/Published online: 15 June 2012 (C) CEERS, IAU 2012

\begin{abstract}
To support environmental risk management in a world heritage city, this paper presents high spatial-resolution maps of air pollutants for the Macao Peninsula. In particular, the risk of exposure to traffic-related nitrogen dioxide pollution for the 22 world heritage monuments in the Historic Center of Macao was assessed. The air-pollution mapping was performed by a building-based air quality model system, in which the traffic-related air pollutions at 5,965 receptor points in the Macao Peninsula were modeled and the average spatial resolution was 727 receptors $/ \mathrm{km}^{2}$. The results indicate that under the conditions of the evening peak hour and the north wind direction sector $0-20^{\circ}$, air quality in the Macao Peninsula is the worst. About $14.1 \%$ of the modeled nitrogen dioxide concentrations at the 5,965 receptor points exceed the national ambient air quality standard for scenic spot of $120 \mu \mathrm{g} / \mathrm{m}^{3}$ in China. Two world heritage monuments, i.e., the "Leal Senado" Building and the Cathedral, are exposed to excessively high nitrogen dioxide concentrations of 135.9 and $121.1 \mu \mathrm{g} / \mathrm{m}^{3}$, respectively. The results in this paper could help decision makers to develop effective strategies to protect the world cultural heritages in Macao for future human generations to appreciate and enjoy.
\end{abstract}

\footnotetext{
N. Sheng

Faculty of Management and Administration,

Macau University of Science and Technology, Macau, China

U. W. Tang $(\bowtie)$

Department of Civil and Environmental Engineering, University of Macau, Macau, China

e-mail: uwtang@gmail.com

U. W. Tang

DSPA, Macau, China
}

Keywords Air quality modeling .

Cultural heritage $\cdot$ Environmental risk management

Geographical information system

\section{Introduction}

Macao is the first place in China open to the West in the sixteenth century. For the preservation of its dramatic mixing of eastern and western cultural relic sites, the Historic Center of Macao has been awarded "World Cultural Heritage" status by the United Nations Educational, Scientific and Cultural Organization in 2005. After the reunification with mainland China in 1999, Macao has experienced a tremendous economic boom. By 2007, the city enclave had become the largest gambling hub in the world and the richest place in Asia in terms of gross domestic product (GDP) per capita. However, the rapid economic development has brought with it associated environmental and social problems (Tang and Sheng 2009).

The urban form of Macao is extremely compact due to population growth and the shortage of land resources. The United Nations World Prospects Report (2004 revised) listed Macao as the No. 1 most densely populated region in the world. In 2011, the population density of the Macao Peninsula is 50,602 inhabitants $/ \mathrm{km}^{2}$. There are 108,178 motorcycles and 85,777 light vehicles, with an increasing rate of 88.3 and $63.7 \%$, respectively, over the past decade (DSEC 2011). The high population density and the lack of control over the number of vehicles cause ever-worsening air quality that endangers the reputation of Macao as a World Cultural Heritage site (De la Fuente et al. 2011; Sheng and Tang 2011a, b). For this reason, there is a need for air-pollution mapping to support effective urban planning and risk management. 
Effective environmental risk management needs to be supported by accurate mapping of air pollutants (Vienneau et al. 2009; Lahr and Kooistra 2010). Studies have shown that the air pollution in an urban area has a complex spatial pattern and levels can vary significantly over small distances (Malakootian and Yaghmaeian 2004; Jerrett et al. 2005; Simkhada et al. 2005; Wilson and Zawar-Reza 2006; Skene et al. 2010; Yassin 2009, 2011). To capture the complex spatial variation of air pollution in an urban area, some researchers have developed geographical information system (GIS)-based models to estimate air-pollution levels at high spatial resolution. Among these, deterministic models based on dispersion modeling include ADMSUrban (McHugh et al. 1997; Carruthers et al. 2000), AirGIS (Jensen 1998; Jensen et al. 2001, 2009; Berkowicz et al. 2008), AERMOD (Kesarkar et al. 2007), STEMS-Air (Gulliver and Briggs, 2011), and others (Elbir 2004; Tang and Wang 2007; Guerrero et al. 2008; Elbir et al. 2010). In particular, a deterministic building-based air quality model system for Macao has been developed by the authors (Tang and Wang 2007; Sheng and Tang 2011a, b). The system integrates the operational street pollution model (OSPM) (Berkowicz 2000), digital maps of the road network, building layout and topographic information, an urban landscape model, and the GIS. The building-based model system has the feature that the street configuration and traffic data can be automatically extracted building by building and therefore, the complex spatial variation of traffic emission, urban geometry, and air pollution can be captured.

This study applied the model system developed by the authors to generate high spatial resolution maps of air pollutants for the Macao Peninsula. The urban areas and populations at potential risk of exposure to traffic-related air pollution were identified. Particularly, the risk for the World Heritage monuments in the Historic Center of Macao was assessed. The results could help decision makers to develop effective strategies to improve air quality and protect the World Cultural Heritages in Macao. The highly compact urban form of the Macao Peninsula may make the findings very relevant to urban planners as they prepare for higher population densities in cities throughout the world. The work presented in this paper was conducted in Macao during 2010 to 2011.

\section{Materials and methods}

Building-based air quality model system

This sub-section provides a brief description of the prototype building-based air quality model system developed by the authors. The model system has a high spatial resolution down to individual buildings along both sides of the street. It is a deterministic model system based on the OSPM and has been evaluated in Macao (Tang and Wang 2007). Interested readers could consult the paper by the authors (Tang and Wang 2007; Sheng and Tang 2011a, b) for more details.

The OSPM model is a parameterized model for flow and dispersion conditions in street canyons (Berkowicz 2000; Berkowicz et al. 2008). Concentrations of exhaust gases are calculated as the sum of the direct contribution from traffic and the recirculation part of the pollutants in the street. The direct contribution is calculated by a plume dispersion model and the recirculation by a box model. In the plume model, the emission field is treated as a number of infinitesimal line sources aligned perpendicular to the wind direction at the street level. It is assumed that the wind direction at street level is a mirror reflection of the wind above roof level. The air pollution is determined by the emission density (per street length and per time), street width, wind speed at the street level, and mechanical turbulence. The mechanical turbulence is assumed to be generated by the wind and by the traffic in the street. When the wind speed is low, the traffic-induced turbulence dominates. For nitrogen oxides, the OSPM model also takes into account simple photochemistry between nitric oxide (NO), nitrogen dioxide $\left(\mathrm{NO}_{2}\right)$, oxygen $\left(\mathrm{O}_{2}\right)$, and ozone $\left(\mathrm{O}_{3}\right)$.

In the prototype model system, an urban landscape model has been developed to integrate the OSPM with the ArcView GIS and automatically extract the street configuration data and traffic data from digital maps. When the urban landscape model is executed, a target building polygon is selected from the cadastral map in ArcView. Based on the coordinates of the vertices of the target building polygon, the boundary segments of the building polygon are obtained. If the boundary segment faces a street aligning parallel to it, it is treated as a building façade which is exposed to direct traffic air pollution and a target receptor point is created in the middle of the boundary segment. The spatial-related input data (street configuration data and traffic data) around the target receptor point are then extracted from the cadastre, road network, and terrain maps for the OSPM.

The modeling results of the OSPM, which include the gaseous concentrations of carbon monoxide (CO), NO, $\mathrm{NO}_{2}$ and benzene are then stored in the attribute fields of the target point feature created in a receptor point map. The spatial-related input variables are also stored in the attribute fields of the receptor point. When all the buildings in the cadastral map are selected and manipulated, the urban landscape model stops the execution. All the modeling results in front of the building façades at roadside can then be accessed from the receptor point map in ArcView. The 
statistical/spatial relationships of the input values and output results can also be investigated.

Input variables

The input variables for the OSPM include street configuration, meteorological data, urban background concentrations, traffic data, and vehicular emissions.

The street configuration data are spatial data that describe the physical street environment surrounding a target receptor point. The data include street width, street length, street orientation, building locations, and building heights, which can be automatically extracted from the cadastre, road network, and terrain maps by the urban landscape model.

Meteorological data include wind speed, wind direction, temperature, and global radiation. Urban background concentrations include those of $\mathrm{CO}, \mathrm{NO}, \mathrm{NO}_{2}$, and $\mathrm{O}_{3}$. The meteorological data and urban background concentrations were obtained from the background monitoring stations of the Macao Meteorological and Geophysical Bureau in the Macao Peninsula.

Traffic data required by the OSPM include traffic volume, composition, and speed. The data were obtained by manual traffic counts on major urban trunk roads and district distributors during the evening peak period (18:00-19:00) on working days in 2010. Diurnal variations on typical traffic roads such as Rua de Campo and Rua da Ribeira do Patane were also observed in an hourly basis. In this study, the traffic composition included five categories of vehicles, i.e., motorcycle, passenger car, taxi, truck, and bus. The category of motorcycle was not included in the original version of the OSPM but was added in this study because motorcycles contribute around half of the traffic volume on majority of the roads in the Macao Peninsula.

The vehicle emission factors are essential input parameters in air quality modeling. In the Macao Peninsula, vehicle emissions are complex due to traffic congestions with rapid exchange of idle, acceleration, cruise, and deceleration modes. To support air quality modeling and management, it is crucial to obtain vehicle emission of individual vehicle during traffic congestion in urban "hot spots" in Macao. The vehicle following measurement under traffic congestion conditions had been conducted by the authors in the urban hot spots in the Macao Peninsula in 2004. A total of 178 vehicles were followed individually and the gaseous emissions $\left(\mathrm{CO}, \mathrm{HC}, \mathrm{NO}, \mathrm{CO}_{2}\right.$, and $\mathrm{O}_{2}$ ) from each preceding vehicle were measured with high-time resolution so that fluctuations in the emissions can be seen readily during vehicle acceleration, cruising, deceleration, and idling. Based on the measurement, the emission factors for five categories of vehicles, i.e., motorcycle, passenger car, taxi, truck, and bus, had been calculated. The details of the vehicle following measurement and the calculation of the emission factors have been reported by Tang and Wang (2006).

\section{Results and discussion}

With the building-based model system, a total of 5,965 receptor point entities were created automatically in front of individual buildings along both sides of the streets in the Macao Peninsula. As the area of lands in the Macao Peninsula is only $8.2 \mathrm{~km}^{2}$ (excluding the $1.1 \mathrm{~km}^{2}$ of a reservoir and two lakes), the average spatial resolution was 727 receptors $/ \mathrm{km}^{2}$. In addition, as the street configuration and traffic data can be extracted building by building, the influence of the complex urban geometry and traffic conditions on air pollution exposures at human respiration height can be taken into account. Human exposures in a city can then be investigated at the address level.

In this study, 18 sets of meteorological conditions and urban backgrounds in different wind direction sectors have been considered in air quality modeling, see Table 1 . The data were obtained from the background monitoring stations of the Macao Meteorological and Geophysical Bureau. The number of effective measurement days in 2010 was 360 days. In each wind direction sector, the measurements of wind direction, wind speed, global radiation, temperature, $\mathrm{NOx}, \mathrm{NO}_{2}$, and $\mathrm{O}_{3}$ during the evening peak hour 18:00-19:00 were averaged and the results are given in Table 1. It is found that the dominated wind direction sector is $80-100^{\circ}$, which was observed on $27.8 \%$ of effective measuring days in 2010 . While there is no record in the wind direction sectors of $200-220^{\circ}$ and $240-260^{\circ}$. The wind speeds are in the range of $1.1-3.3 \mathrm{~m} / \mathrm{s}$ and the global radiations are in the range of $0.0-12.4 \mathrm{~W} / \mathrm{m}^{2}$. The global radiations are relatively low as values refer to the radiations in the evening. As the Macao Peninsula is located in the sub-tropical region, the temperatures are in the range of $17.7-31.0^{\circ} \mathrm{C}$. For urban backgrounds, $\mathrm{NOx}$ and $\mathrm{NO}_{2}$ concentrations are in the range of $21.7-121.2 \mu \mathrm{g} / \mathrm{m} 3$ and $14.8-90.3 \mu \mathrm{g} / \mathrm{m}^{3}$, respectively. While $\mathrm{O}_{3}$ concentrations are in the range of $25.3-168.2 \mu \mathrm{g} / \mathrm{m}^{3}$.

Statistical results for modeled $\mathrm{NO}_{2}$ concentrations under different meteorological conditions and urban backgrounds in the 18 wind direction sectors are shown in Table 2. It is found that when winds blow from the south direction of $180-200^{\circ}$, the air quality in the Macao Peninsula is the best. The average, minimum, and maximum values of $\mathrm{NO}_{2}$ concentrations at the 5,965 receptor points are, respectively, 20.8, 15.2, and $47.7 \mu \mathrm{g} / \mathrm{m}^{3}$, which are the lowest among the 18 wind direction sectors. This could be explained by the fact that the Macao Peninsula and its outer islands face the South China Sea in the south and the urban 
Table 1 Meteorological conditions and urban backgrounds

\begin{tabular}{|c|c|c|c|c|c|c|c|c|}
\hline $\begin{array}{l}\text { Wind } \\
\text { direction } \\
\text { sector } \\
\text { (degree) }\end{array}$ & $\begin{array}{l}\text { Frequency } \\
(\%)\end{array}$ & $\begin{array}{l}\text { Average wind } \\
\text { direction } \\
\text { (degree) }\end{array}$ & $\begin{array}{l}\text { Average wind } \\
\text { speed }(\mathrm{m} / \mathrm{s})\end{array}$ & $\begin{array}{l}\text { Average global } \\
\text { radiation }\left(\mathrm{W} / \mathrm{m}^{2}\right)\end{array}$ & $\begin{array}{l}\text { Average } \\
\text { temperature } \\
\left({ }^{\circ} \mathrm{C}\right)\end{array}$ & $\begin{array}{l}\text { Average } \mathrm{NO}_{\mathrm{x}} \\
\left(\mu \mathrm{g} / \mathrm{m}^{3}\right)\end{array}$ & $\begin{array}{l}\text { Average } \mathrm{NO}_{2} \\
\left(\mu \mathrm{g} / \mathrm{m}^{3}\right)\end{array}$ & $\begin{array}{l}\text { Average } \mathrm{O}_{3} \\
\left(\mu \mathrm{g} / \mathrm{m}^{3}\right)\end{array}$ \\
\hline $0-20$ & 1.7 & 12.8 & 1.7 & 0.5 & 21.5 & 121.2 & 90.3 & 44.7 \\
\hline $20-40$ & 2.5 & 33.7 & 1.7 & 2.2 & 22.4 & 96.1 & 74.0 & 47.7 \\
\hline $40-60$ & 1.4 & 42.6 & 1.4 & 0.0 & 18.0 & 91.2 & 73.6 & 45.1 \\
\hline $60-80$ & 1.7 & 69.0 & 2.5 & 1.9 & 21.9 & 94.0 & 70.2 & 30.6 \\
\hline 80-100 & 27.8 & 90.8 & 2.2 & 1.6 & 22.1 & 77.5 & 56.9 & 52.7 \\
\hline $100-120$ & 16.1 & 108.7 & 2.0 & 4.4 & 24.3 & 54.5 & 42.3 & 59.7 \\
\hline $120-140$ & 2.5 & 134.6 & 1.5 & 6.8 & 25.8 & 35.1 & 25.7 & 37.7 \\
\hline $140-160$ & 4.2 & 159.3 & 2.2 & 0.9 & 24.6 & 28.3 & 21.5 & 39.0 \\
\hline $160-180$ & 9.7 & 174.5 & 1.9 & 10.2 & 28.1 & 25.8 & 17.2 & 41.8 \\
\hline $180-200$ & 8.6 & 185.6 & 2.6 & 12.4 & 29.2 & 21.7 & 14.8 & 25.3 \\
\hline $200-220$ & 0.0 & - & - & - & - & - & - & - \\
\hline $220-240$ & 0.6 & 223.0 & 1.1 & 6.9 & 29.6 & 29.2 & 22.7 & 39.4 \\
\hline $240-260$ & 0.0 & - & - & - & - & - & - & - \\
\hline $260-280$ & 1.7 & 269.5 & 2.1 & 6.0 & 27.8 & 30.0 & 15.8 & 32.9 \\
\hline $280-300$ & 1.1 & 290.0 & 1.8 & 2.1 & 31.0 & 49.7 & 38.7 & 168.2 \\
\hline $300-320$ & 12.2 & 315.3 & 2.5 & 0.5 & 18.0 & 107.4 & 68.6 & 44.7 \\
\hline $320-340$ & 4.4 & 336.0 & 3.3 & 0.0 & 17.7 & 84.0 & 50.5 & 47.3 \\
\hline $340-360$ & 3.9 & 354.9 & 2.6 & 0.2 & 21.9 & 76.4 & 60.9 & 65.2 \\
\hline
\end{tabular}

Table 2 Modeling results in various wind direction sector

\begin{tabular}{lcccc}
\hline $\begin{array}{l}\text { Wind direction } \\
\text { sector (degree) }\end{array}$ & $\begin{array}{l}\text { Average } \mathrm{NO}_{2} \\
\left(\mu \mathrm{g} / \mathrm{m}^{3}\right)\end{array}$ & $\begin{array}{l}\mathrm{Min} . \mathrm{NO}_{2} \\
\left(\mu \mathrm{g} / \mathrm{m}^{3}\right)\end{array}$ & $\begin{array}{l}\mathrm{Max} . \mathrm{NO}_{2} \\
\left(\mu \mathrm{g} / \mathrm{m}^{3}\right)\end{array}$ & $\begin{array}{l}\text { Exceed } \mathrm{NO}_{2} \\
\text { standard } \\
\left(>120 \mu \mathrm{g} / \mathrm{m}^{3}\right)\end{array}$ \\
\hline $0-20$ & 111.7 & 99.3 & 139.8 & 14.1 \\
$20-40$ & 95.8 & 81.2 & 132.3 & 0.5 \\
$40-60$ & 93.7 & 79.4 & 131.9 & 0.3 \\
$60-80$ & 82.6 & 72.3 & 110.7 & 0.0 \\
$80-100$ & 76.1 & 60.1 & 111.1 & 0.0 \\
$100-120$ & 59.0 & 44.3 & 104.7 & 0.0 \\
$120-140$ & 37.3 & 26.6 & 68.5 & 0.0 \\
$140-160$ & 31.6 & 22.9 & 67.1 & 0.0 \\
$160-180$ & 28.2 & 18.4 & 64.6 & 0.0 \\
$180-200$ & 20.8 & 15.2 & 47.7 & 0.0 \\
$200-220$ & - & - & - & - \\
$220-240$ & 36.4 & 24.4 & 83.7 & 0.0 \\
$240-260$ & - & - & - & - \\
$260-280$ & 26.8 & 17.2 & 63.9 & 0.0 \\
$280-300$ & 68.8 & 43.4 & 179.0 & 4.0 \\
$300-320$ & 91.3 & 76.3 & 116.1 & 0.0 \\
$320-340$ & 65.3 & 54.1 & 91.3 & 0.0 \\
$340-360$ & 77.7 & 66.3 & 118.0 & 0.0 \\
\hline & & & & \\
\hline
\end{tabular}

background of $\mathrm{NO}_{2}$ concentration in the wind direction sector $180-200^{\circ}$ is the lowest among the 18 wind direction sectors (i.e., $14.8 \mu \mathrm{g} / \mathrm{m}^{3}$, Table 1).
On the other hand, when winds blow from the north direction of $0-20^{\circ}$, the air quality in the Macao Peninsula is the worst. Comparing with the wind direction sector 
$180-200^{\circ}$, the wind speed in the north wind direction sector $0-20^{\circ}$ is $35 \%$ lower and the background $\mathrm{NO}_{2}$ is 6.1 times higher (Table 1). The lower wind speed leads to worse dispersion conditions while the higher background concentration of $\mathrm{NO}_{2}$ leads to higher total concentration of $\mathrm{NO}_{2}$. As a result, under the conditions of the north wind direction sector $0-20^{\circ}$ and the evening peak hour, the average value of $\mathrm{NO}_{2}$ concentrations at the 5,965 receptor points is $111.7 \mu \mathrm{g} / \mathrm{m}^{3}$, which is the highest among the 18 wind direction sectors. In addition, about $14.1 \%$ of the receptor points are exposed to $\mathrm{NO}_{2}$ concentrations which exceeded the national Ambient Air Quality Standard for Scenic Spot of $120 \mu \mathrm{g} / \mathrm{m} 3$ (GB3095-1996) (State of Environmental Protection Administration of China 1996).

Based on the modeling results at 5,965 receptor points, the distribution maps of $\mathrm{NO}_{2}$ under the conditions of the dominated wind direction sector $80-100^{\circ}$ and the north wind direction sector $0-20^{\circ}$ are generated as shown in Figs. 1, 2, respectively. It is observed from Figs. 1, 2 that $\mathrm{NO}_{2}$ concentrations are the highest in the high-rise residential areas, in the central business district (CBD), and along the inner circumferential routes, which attracted heavy traffic and thus induced intense vehicle emissions.

Figure 1 indicates that under the conditions of the dominated wind direction sector $80-100^{\circ}$ and the evening peak hour, the modeled $\mathrm{NO}_{2}$ concentrations at all the 5,965 receptor points do not exceed the national Ambient Air

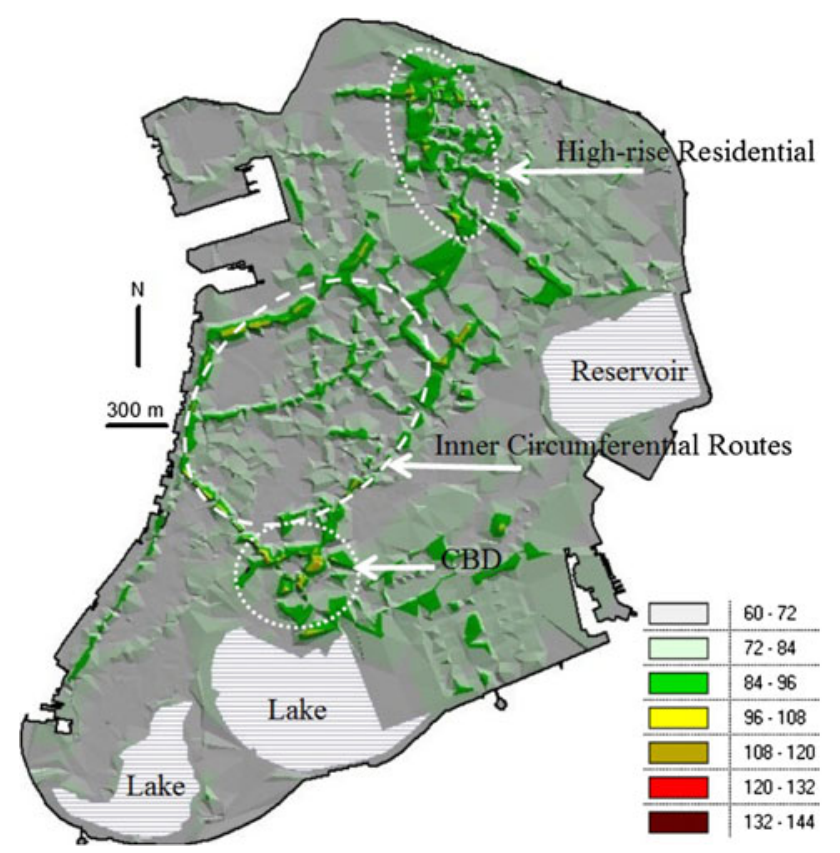

Fig. 1 Spatial distribution of $\mathrm{NO}_{2}\left(\mu \mathrm{g} / \mathrm{m}^{3}\right)$ in dominated wind direction sector $80-100^{\circ}$

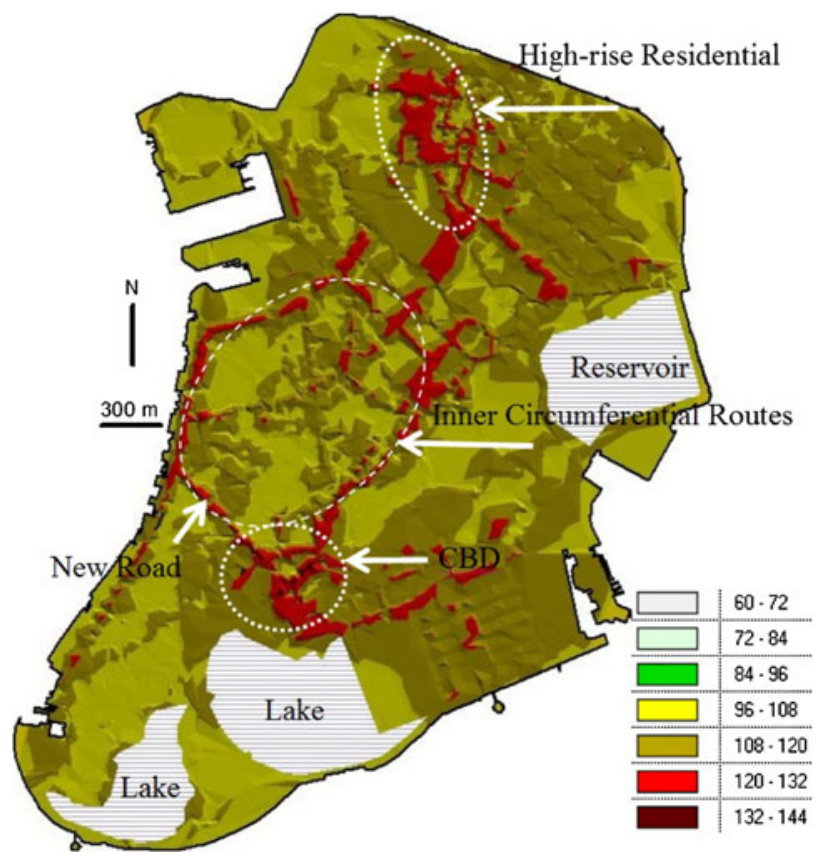

Fig. 2 Spatial distribution of $\mathrm{NO}_{2}\left(\mu \mathrm{g} / \mathrm{m}^{3}\right)$ in north wind direction sector $0-20^{\circ}$

Quality Standard for Scenic Spot of $120 \mu \mathrm{g} / \mathrm{m}^{3}$. However, under the conditions of the north wind direction sector $0-20^{\circ}$ and the evening peak hour (Fig. 2), about $14.1 \%$ of $\mathrm{NO}_{2}$ concentrations at the 5,965 receptor points in the Macao Peninsula exceed $120 \mu \mathrm{g} / \mathrm{m}^{3}$. Particularly, about $0.5 \%$ of the receptor points have $\mathrm{NO}_{2}$ concentrations higher than $132 \mu \mathrm{g} / \mathrm{m}^{3}$, which exceeds $10 \%$ of the air quality standard of $120 \mu \mathrm{g} / \mathrm{m}^{3}$. As seen from Fig. 2, the red and dark red areas are at a high risk of exposure to air pollution $\left(\mathrm{NO}_{2}\right.$ concentrations $\left.>120 \mu \mathrm{g} / \mathrm{m}^{3}\right)$. The worst air quality occurs in the CBD $\left(\mathrm{NO}_{2}\right.$ concentrations $\left.>132 \mu \mathrm{g} / \mathrm{m}^{3}\right)$.

In this study, the traffic-related $\mathrm{NO}_{2}$ pollutions at the 22 World Heritage monuments in the Historic Center of Macao have been further investigated to support effective risk management and protection for the World Heritage. Figure 3 shows the spatial distribution of the 22 World Heritage monuments. The modeled $\mathrm{NO}_{2}$ concentrations at the 22 monuments are given in Table 3 . Under the conditions of the dominated wind direction sector $80-100^{\circ}$ and the evening peak hour, $\mathrm{NO}_{2}$ concentrations at all the monuments do not exceed the national Ambient Air Quality Standard for Scenic Spot $\left(120 \mu \mathrm{g} / \mathrm{m}^{3}\right)$. The highest $\mathrm{NO}_{2}$ concentration of $99.9 \mu \mathrm{g} / \mathrm{m}^{3}$ (i.e., $83 \%$ of the allowed limit) is observed in the "Leal Senado" Building (No.9), followed by the St. Anthony's Church (No.19), the Cathedral (No.12), and the A-Ma Temple (No.1).

Under the conditions of the north wind direction sector 0-20 and the evening peak hour, the "Leal Senado" Building (No.9) and the Cathedral (No.12) are exposed to 


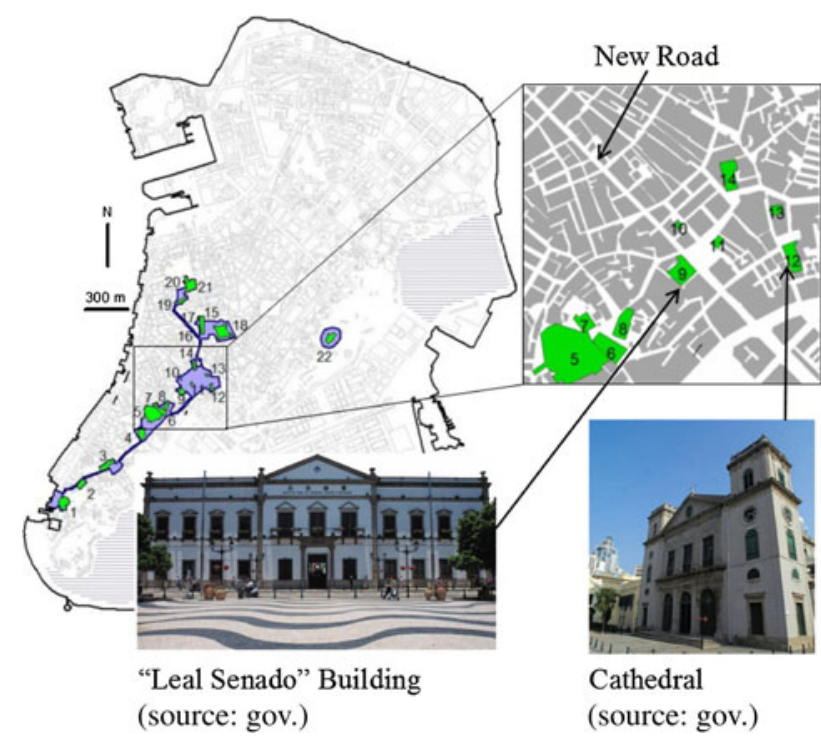

Fig. 3 Monuments in the Historic Center of Macao (1 A-Ma Temple, 2 Moorish Barracks, 3 Mandarin's House, 4 St. Lawrence's Church, 5 St. Joseph's Seminary and Church, 6 Dom Pedro V Theatre, 7 Sir Robert Ho Tung Library, 8 St. Augustine's Church, 9 "Leal Senado" Building, 10 Sam Kai Vui Kun (Kuan Tai Temple), 11 Holy House of Mercy, 12 Cathedral, 13 Lou Kau Mansion, 14 St. Dominic's Church, 15 Ruins of St. Paul's, 16 Na Tcha Temple, 17 Section of the Old City Walls, 18 Mount Fortress, 19 St. Anthony's Church, 20 Casa Garden, 21 Protestant Cemetery, 22 Guia Fortress) excessive high $\mathrm{NO}_{2}$ concentrations of 135.9 and 121.1 $\mu \mathrm{g} / \mathrm{m}^{3}$, which exceed the national Ambient Air Quality Standard for Scenic Spot of $120 \mu \mathrm{g} / \mathrm{m}^{3}$. In particular, the $\mathrm{NO}_{2}$ concentration at the "Leal Senado" Building (No. 9) exceeds $13 \%$ of the allowed limit. Originally built in 1784 , the building was Macao's original municipal chamber, a function it maintains to the present. The building is located on the New Road, which is part of the inner circumferential routes at present (Fig. 2). As shown in Fig. 3, the New Road is a long straight road passing through the historical area with narrow and complex curvature road network. The complex curvature road network was developed in an organic style of urban development by Portuguese explorers in the hilly historic area in the sixteenth century. At that time, people usually walked to destinations and thus the roads were designed for pedestrian use. In 1918, the Portuguese removed a small hill and some buildings to build a wider and straight New Road to facilitate modern vehicle transport passing through the historical area. Today's drivers select the straight New Road rather than the other complex curved roads to pass through the historical area, which leads to a significantly higher traffic volume (greater than 1,500 vehicles per hour) and hence, the worst air quality at the "Leal Senado" Building (No.9) among the 22 World Heritage monuments.
Table $3 \quad \mathrm{NO}_{2}$ concentrations at the World Heritage monuments

\begin{tabular}{lll}
\hline World heritage monuments & $\mathrm{NO}_{2}\left(\mu \mathrm{g} / \mathrm{m}^{3}\right)$ & \\
\cline { 2 - 3 } & Wind sector & Wind sector \\
& $80-100^{\circ}$ & 115.8 \\
\hline 1. A-Ma Temple & 78.9 & 110 \\
2. Moorish Barracks & 75.1 & 111.4 \\
3. Mandarin's House & 78.8 & 113 \\
4. St. Lawrence's Church & 69.4 & 114 \\
5. St. Joseph's Seminary and Church & 73 & 105.6 \\
6. Dom Pedro V Theatre & 71.7 & 110.1 \\
7. Sir Robert Ho Tung Library & 70.4 & 109.7 \\
8. St. Augustine's Church & 69.5 & 135.9 \\
9. "Leal Senado" Building & 99.9 & 106.5 \\
10. Sam Kai Vui Kun (Kuan Tai Temple) & 68.7 & 105.3 \\
11. Holy House of Mercy & 68.4 & 121.1 \\
12. Cathedral & 84.8 & 107.7 \\
13. Lou Kau Mansion & 69.4 & 105.8 \\
14. St. Dominic's Church & 68.7 & 108.2 \\
15. Ruins of St. Paul's & 66.5 & 103 \\
16. Na Tcha Temple & 67.6 & 103 \\
17. Section of the Old City Wall & 67.6 & 108.5 \\
18. Mount Fortress & 76 & 107.8 \\
19. St. Anthony's Church & 93.8 & 104.2 \\
20. Casa Garden & 67.4 & 106.4 \\
21. Protestant Cemetery & 68.5 & 107.3 \\
22. Guia Fortress & 69.3 & \\
\hline
\end{tabular}




\section{Conclusion}

This study has applied a building-based air quality model system to generate high spatial resolution maps of traffic-related $\mathrm{NO}_{2}$ based on the modeling results at 5,965 receptor points in the Macao Peninsula. The results indicate that under the conditions of the evening peak hour and the north wind direction sector $0-20^{\circ}$, air quality in the Macao Peninsula is the worst. About $14.1 \%$ of the modeled $\mathrm{NO}_{2}$ concentrations at the 5,965 receptor points exceed the national Ambient Air Quality Standard for Scenic Spot of $120 \mu \mathrm{g} / \mathrm{m}^{3}$. The CBD, the high-rise residential areas, and the inner circumferential routes are at a high risk of exposure to traffic-related air pollution $\left(\mathrm{NO}_{2}\right.$ concentrations $>120 \mu \mathrm{g} / \mathrm{m}^{3}$ ). The worst air quality occurs in the CBD $\left(\mathrm{NO}_{2}\right.$ concentrations $\left.>132 \mu \mathrm{g} / \mathrm{m}^{3}\right)$.

The risk of exposure to traffic-related $\mathrm{NO}_{2}$ pollution for the 22 World Heritage monuments in the Historic Center of Macao has been further assessed. The results indicate that under the conditions of the evening peak hour and the north wind direction sector $0-20^{\circ}$, two monuments (i.e., the "Leal Senado" Building and the Cathedral) are exposed to excessive high $\mathrm{NO}_{2}$ concentrations of $121.1-135.9 \mu \mathrm{g} / \mathrm{m}^{3}$. The worst air quality occurs at the "Leal Senado" Building among the 22 World Heritage monuments.

According to the United Nations, World Heritage is the designation for places on earth that are of outstanding universal value to be protected for future human generations to appreciate and enjoy. The results in this paper could help decision makers to develop effective strategies to improve air quality and protect the World Cultural Heritages in Macao.

Acknowledgments The first author was supported by the Macau Foundation and Macau University of Science and Technology under Grand No. 0126.

\section{References}

Berkowicz R (2000) OSPM: a parameterised street pollution model. Environ Monitor Assess 65(1/2):323-331

Berkowicz R, Ketzel M, Jensen SS, Hvidberg M, Raaschou-Nielsen O (2008) Evaluation and application of OSPM for traffic pollution assessment for a large number of street locations. Environ Model Softw 23:296-303

Carruthers DJ, Edmunds HA, Lester AE, McHugh CA, Singles RA (2000) Use and validation of ADMS-Urban in contrasting urban and industrial environments. Int J Environ Pollut 14:1-6

De la Fuente D, Vega JM, Viejo F, Díaz I, Morcillo M (2011) City scale assessment model for air pollution effects on the cultural heritage. Atmos Environ 45:1242-1250

DSEC (2011) Statistics and Census Service, Macao SAR Government. Retrieved 19 August 2011

Elbir T (2004) A GIS based decision support system for estimation, visualization and analysis of air pollution for large Turkish cities. Atmos Environ 38:4509-4517
Elbir T, Mangir N, Kara M, Simsir S, Eren T, Ozdemir S (2010) Development of a GIS-based decision support system for urban air quality management in the city of Istanbul. Atmos Environ 44:441-454

Guerrero PJ, Jorba O, Baldasano JM, Gasso S (2008) The use of a modeling system as a tool for air quality management: annual high-resolution simulations and evaluation. Sci Total Environ 390:323-340

Gulliver J, Briggs D (2011) STEMS-Air: a simple GIS-based air pollution dispersion model for city-wide exposure assessment. Sci Total Environ 409:2419-2429

Jensen SS (1998) Mapping human exposure to traffic air pollution using GIS. J Hazard Mater 61(1-3):385-392

Jensen SS, Berkowicz R, Hansen HS, Hertel O (2001) A Danish decision-support GIS tool for management of urban air quality and human exposures. Transport Res Part D-Trans Environ 6:229-241

Jensen SS, Larson T, Deepti KC, Kaufman JD (2009) Modeling traffic air pollution in street canyons in New York City for intra-urban exposure assessment in the US multi-ethnic study of atherosclerosis and air pollution. Atmos Environ 43:4544-4556

Jerrett M, Arain A, Kanaroglou P, Beckerman B, Potoglou D, Sahsuvaroglu T, Morrison J, Giovis C (2005) A review and evaluation of intraurban air pollution exposure models. J Exposure Anal Environ Epidemiol 15(2):185-204

Kesarkar AP, Dalvi M, Kaginalkar A, Ojha A (2007) Coupling of the weather research and forecasting model with AERMOD for pollutant dispersion modeling. A case study for PM10 dispersion over Pune, India. Atmos Environ 41(9):1976-1988

Lahr J, Kooistra L (2010) Environmental risk mapping of pollutants: state of the art and communication aspects. Sci Total Environ 408:3899-3907

Malakootian M, Yaghmaeian K (2004) Investigation of carbon monoxide in heavy traffic intersections of municipal districts. Int J Environ Sci Tech 1:227-231

McHugh CA, Carruthers DJ, Edmunds HA (1997) ADMS and ADMS-Urban. Int J Environ Pollut 8:438-440

Sheng N, Tang UW (2011a) Spatial analysis of urban form and pedestrian exposure to traffic noise. Int J Environ Res Public Health 8:1977-1990

Sheng N, Tang UW (2011b) A building-based data capture and data mining technique for air quality assessment. Front Environ Sci Eng China 5:543-551

Simkhada K, Murthy VK, Khanal SN (2005) Assessment of ambient air quality in Bishnumati corridor, Kathmandu metropolis. Int $\mathbf{J}$ Environ Sci Tech 2:217-222

Skene KJ, Gent JF, McKay LA, Belanger K, Leaderer BP, Holford TR (2010) Modeling effects of traffic and landscape characteristics on ambient nitrogen dioxide levels in Connecticut. Atmos Environ 44:5156-5164

State of Environmental Protection Administration of China (1996) Ambient air quality standard (GB3095-1996). China Environmental Science Press, Beijing

Tang UW, Sheng N (2009) City profile: Macao. Cities 26:220-231

Tang UW, Wang ZS (2006) Determining gaseous emission factors and driver's particle exposures during traffic congestion by vehicle-following measurement techniques. J Air Waste Manage Assoc 56:1532-1539

Tang UW, Wang ZS (2007) Influences of urban forms on trafficinduced noise and air pollution: results from a modeling system. Environ Model Softw 22:1750-1764

United Nations World Population Prospects (2004 revision). UN Statistics Division. Retrieved 2008-01-07

Vienneau D, de Hoogh K, Briggs D (2009) A GIS-based method for modelling air pollution exposures across Europe. Sci Total Environ 408:255-266 
Wilson JG, Zawar-Reza P (2006) Intraurban-scale dispersion modelling of particulate matter concentrations: applications for exposure estimates in cohort studies. Atmos Environ 40:1053-1063

Yassin MF (2009) Numerical simulation on pollutant dispersion from vehicle exhaust in street configurations. Environ Monitor Assess $156: 257-273$
Yassin MF (2011) Impact of height and shape of building roof on air quality in urban street canyons. Atmos Environ 45:5220-5229 